\title{
Under and over: location, uses and discontinuities in a centrally located neighbourhood in João Pessoa city reflecting current urban planning effects
}

Por baixo e através: localização, usos e descontinuidades em uma vizinhança central na cidade de João Pessoa refletindo efeitos do planejamento urbano corrente

Lucy Donegan[a] @ ( José Augusto Ribeiro da Silveira[a], Geovany Jessé Alexandre da Silva[a] (1)

[a] Universidade Federal da Paraíba (UFPB), João Pessoa, PB, Brasil

How to cite: Donegan, L., Silveira, J. A. R., \& Silva, G. J. A. (2019). Under and over: location, uses and discontinuities in a centrally located neighbourhood in João Pessoa city reflecting current urban planning effects. urbe. Revista Brasileira de Gestão Urbana, 11, e20180123. https://doi.org/10.1590/2175-3369.011.e20180123

\section{Abstract}

This paper compares spatial configuration, built form and uses at Tambauzinho and Tambaú areas, in João Pessoa, Brazil. Although it is located between the old city centre and its expansion towards the coast, Tambauzinho presents little urban vitality, different from the expected in a central location, and to what happens in Tambaú. Understanding cities as problems in organized complexity, and that space configures fields of potential movement and encounters, physical attributes work together to facilitate urban vitality. The potential movement to and through places at various scales (according to space syntax framework) were analysed for the city and the areas and compared with built form and uses. Both areas' urban grid present high potential movement; however at Tambauzinho, local physical attributes and a highway crossing the neighbourhood hinder more legibility and walkability, interrupting local flows and visual and physical connections at street level, with poor qualities of sidewalks. Limited urban vitality in Tambauzinho is underlined by non-residential uses mostly concentrating at the areas' northern periphery, whereas at Tambaú, they spread more throughout the area. Problems at Tambauzinho express a mainly vehicular oriented urban planning; understanding negative consequences aims to build knowledge, alleviating problems and re-directing future interventions.

Keywords: Urban vitality. Spatial configuration. Tambauzinho and Tambaú. Land uses. João Pessoa.

\section{Resumo}

Este artigo compara a configuração espacial, forma construída e usos em Tambauzinho, João Pessoa, Brasil. Apesar de situada entre o centro antigo e a expansão ao litoral, Tambauzinho apresenta baixa vitalidade urbana, diferente do esperado em uma localização central, e ao que acontece em Tambaú. Entendendo cidades como problemas em complexidade organizada, e que o espaço configura campos potenciais de movimento e encontro, atributos físicos trabalham em conjunto para facilitar vitalidade urbana. Movimentos potenciais para, e entre, lugares em escalas diversas (conforme o referencial da sintaxe do espaço) foram

LD is architect and urbanist (UFC), masters and PhD in Architecture and Urbanism (UFRN), e-mail: lucydonegan@gmail.com JARS is architect and urbanist (UFPE), masters and PhD in Urban Development (UFPE), e-mail: ct.laurbe@gmail.com

GJAS is architect and urbanist (UFU), masters in Geography (UFMG), PhD in Architecture and Urbanism (UnB), e-mail: galexarq.ufpb@gmail.com 
analisados para a cidade e para as áreas, e comparados com forma construída e usos. Apesar de a malha urbana das áreas apresentar elevado movimento potencial, em Tambauzinho atributos físicos locais e uma rodovia que atravessa vizinhança dificultam legibilidade e caminhabilidade, interrompendo fluxos locais, conexões visuais e físicas na rua, com baixa qualidade das calçadas. Vitalidade urbana limitada é enfatizada por usos não residenciais concentrados na periferia norte da área, enquanto em Tambaú se espalham mais. Problemas expressam um planejamento urbano direcionado para movimento veicular; o entendimento de consequências negativas objetiva construir conhecimento para amenizar problemas e redirecionar intervenções futuras.

Palavras-chave: Vitalidade urbana. Configuração espacial. Tambauzinho e Tambaú. Usos do solo. João Pessoa.

\section{Introducing the problem}

This paper compares spatial configuration - at varied modes and scales of analysis - built form and uses at Tambauzinho, in João Pessoa city, Brazil. The area is centrally located between the old city centre and expansion areas towards the coast, now a consolidated urban area. Its central location and grid distribution point towards a livelier area than what we find there. This paper argues that, in spite of its' location, the area remains a mostly low-rise residential area at least partly due to local urban design severances fruit from a mainly vehicular oriented planning. In comparison, another neighbourhood Tambaú (here including Tambaú and North Miramar), located on the other side of the same expansion route, is more continuous in street level connections and has a more diverse built profile.

According to tendencies in other Brazilians cities (Villaça, 2001), João Pessoa had a rapid linear growth, characterised by a mainly vehicular oriented planning, formed by an urban grid with discontinuous patches. This situation stands opposed to more ideally dense and diversely knitted cities (Alexander, 1965; Jacobs, 1992; Berghauser Pont \& Haupt, 2005) that facilitate the combination of different modes of transportation, especially walking.

João Pessoa is the capital city of Paraíba state, located in the Brazilian north-east region (Figure 1). The city was founded close to Paraíba's estuary constituted by a mainly irregular grid, now the old city centre. Main routes expanded from the old city centre in a radial-concentric manner (Silveira et al., 2007). Epitácio Pessoa Avenue stands out connecting the old city centre to the coast, a straight line of over $5 \mathrm{~km}$ long that reaches Cabo Branco's coastal neighbourhood. The coast was at first far-away from more consolidated urban areas, and this avenue facilitated the urban grid occupation; coastal neighbourhoods (Tambaú and Cabo Branco) were occupied and consolidated before the urban void was filled towards Tambauzinho, as was the situation up to the 1960s (Castro et al., 2016).

Tambauzinho is located mid-way in this expansion, south of Epitácio Pessoa Avenue. The area hereby studied as Tambauzinho encompasses partially neighbouring areas of Expedicionários and southern Miramar. The area is cut transversely by BR $230^{1}$ highway, which reaches Campina Grande city and continues on to connect the Amazon region. Although located centrally within João Pessoa, Tambauzinho resembles a thoroughfare rather than a centrally diverse and lively area within the city. Such situation is expressed, as analysed in this paper, by little distribution of non-residential uses, mobility infrastructure and amenities, expressing the difficulty for pedestrians to move in and through the neighbourhood. In comparison, Tambaú (here encompassing the northern fraction of Miramar and Tambaú neighbourhoods) located following Epitácio Pessoa's expansion further east by the coast is a livelier area hosting many commercial and services, and, in spite of building restrictions, has medium to high-rise residential buildings. To facilitate comparison, Tambauzinho and Tambaú areas are sometimes referred to as, respectively, Fractions 1 and 2 (Figure 1).

\footnotetext{
${ }^{1}$ Nomenclature for federal highway.
} 


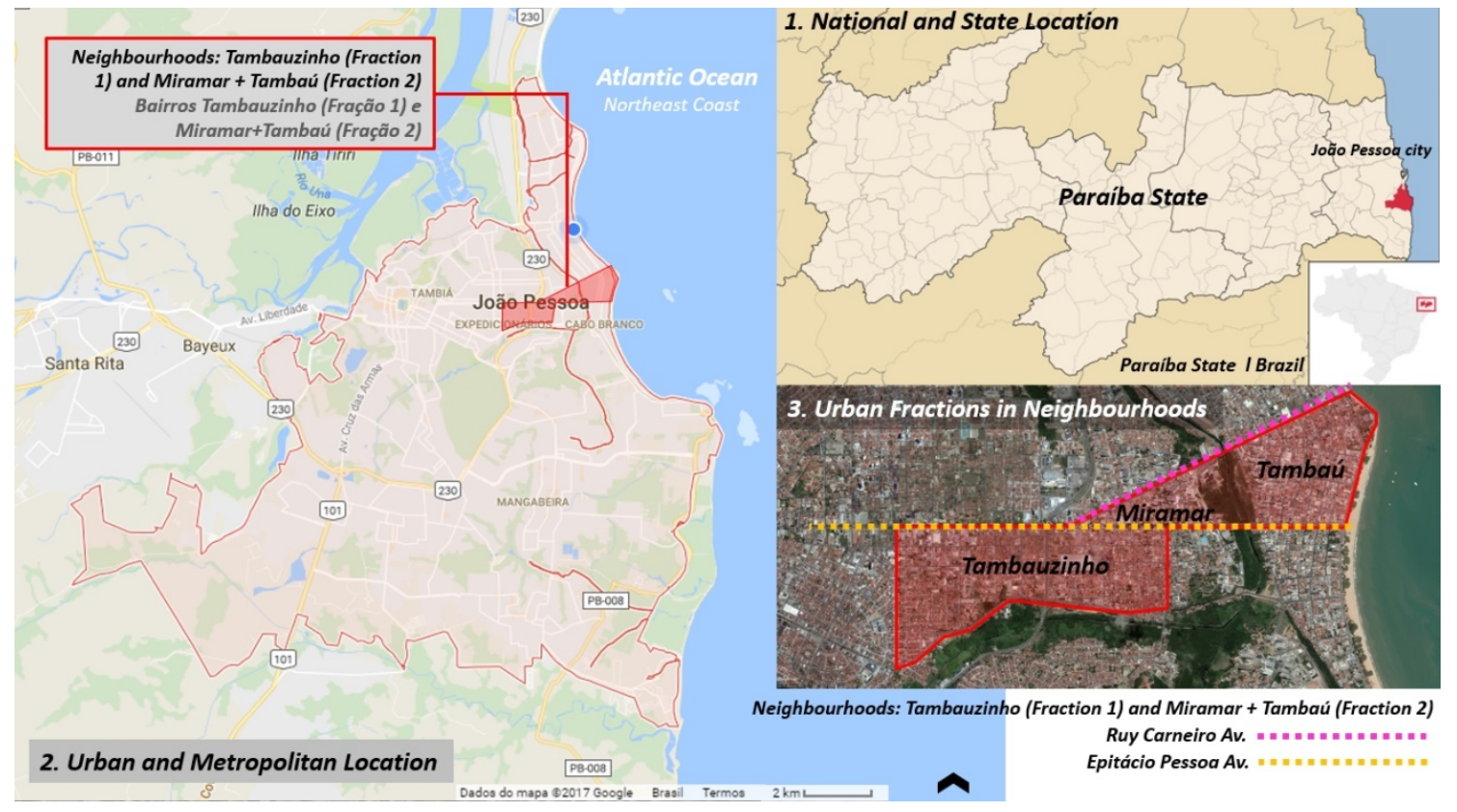

Figure 1 - Studied cases location in João Pessoa city, and the city's location within Paraíba State, Brazil. Source: Adapted and Edited from Google Maps (2017).

This paper focuses on spatial configuration, built form in the area and observed uses, related to other spatial attributes such as sidewalk qualities and potential interfaces. To deepen our knowledge on modes of use and relate these in a finer grain to physical built attributes, the next research stage will focus on quantifying flows of people on different locations and survey types of interfaces between public and private areas.

The next topic presents the main theoretical background, which lay foundations for the study methodology. The paper follows in presenting the study case and its context within João Pessoa's expansion, the research methodology, analysis and, finally, conclusions.

\section{Theoretical framework}

Cities are problems in organized complexity (Jacobs, 1992). Many physical attributes work together to promote urban vitality. Complementarily, spatial form configures potential fields of movement which might help unite and separate people (Peponis, 1989), and affect modes of use.

Criticisms have long been made to mono-functional modernist planning of cities mainly focused on vehicular movement. Peoples' actual uses in the city demand more journey overlaps, as they tend to perform diverse and complementary activities in one trip (Alexander, 1965). Jacobs (1992) highlighted factors contributing to urban vitality, such as mixed land uses, small blocks allowing for many different routes to be taken and decreasing travel distances, the coexistence between buildings from different eras and sufficient density.

Diversity of uses has been interpreted as an expression of urban vitality (Vaughan et al., 2013, 2015), as different people perform different and complementary activities within an area. In this sense urban space might be able to reassemble what society has divided (Vaughan et al., 2017). At street level, strong interfaces between private and public spaces has shown to facilitate urban life and less vulnerability (Ferraz, 2008; Van Nes \& López, 2007), providing instances of natural surveillance (Jacobs, 1992).

Space syntax theory and methodology provides a framework to analyse objective physical attributes of open urban spaces related to peoples tendency to walk in lines, see visual fields as they move, and 
meet in convex spaces (Hillier \& Hanson, 1984; Hillier \& Vaughan, 2007). Studies have related the urban grid's spatial configuration as promoting degrees of potential movement, i.e. topological accessibilities (Hillier, 1996; Hillier et al., 1993). Such dynamics help shape the location of certain uses within the city: in order to take advantage of such potential movement certain uses (as commercial activities), locate themselves in areas with high accessibility; by their turn, these uses help attract more movement, creating a cycle. In Natal city (Capital of the Rio Grande do Norte State, Brazil) high potential movement configured by the grid characterized different uses - e.g. large scale commerce in Ponta Negra neighbourhood (Nascimento, 2011), and areas with high building renewals (Medeiros et al., 2009). Relating spatial configuration with built form helped understand urban dynamics, and relations between potential flows and other physical attributes, as types of interfaces, building heights, as well as to activities taking place in certain areas (Donegan \& Trigueiro, 2016).

Accessibilities configured by the urban grid are categorized into (i) potential to-movement (integration) as a measure of centrality in the system, of how easy it is to access all other spaces from one space, and seen to relate to the flow of visitors (Hillier, 2009) and (ii) potential through-movement (choice) as a measure of betweenness in the system, of how likely a certain route might be chosen as a shortcut within a origin-destination, and was seen to related to flows of inhabitants (Hillier, 2009). Accessibilities are measured by graph analysis, each spatial entity representing a node. In axial analysis each contact between lines of potential movement forms a connection. Integration relates to the mean-depth of one space to all other spaces in the system, forming a justified graph in which each spatial change represents a depth level: segregated spaces present deeper graphs, whereas integrated spaces are shallower, reaching other spaces with few level changes. Choice is measured by the likeliness of one space being chosen as the shortest route between sets of origin-destination. For Choice measures one value is deposited for each possible decision for different routes to be taken, thus measures vary according to the system size. Normalized values of accessibilities were created to compare systems of different sizes (Hillier et al., 2012). Areas with positive correlations between integration and choice at different metric scales presented more diversity of activities and people (Vaughan et al., 2013), and were better embedded within the wider urban fabric (Yang \& Hillier, 2012). These findings reinforce the role of the grid promoting certain types of uses and as a mechanism to help bring people and activities together.

However, other spatial attributes influence peoples uses and urban vitality, as the qualities of visual connections and interfaces considering the viewpoint of people at street level. "Visual connections are necessary for orientation, and for creating a coherent picture of an urban setting" (Salingaros, 1998, p. 55). The importance of interdependencies between movement at different scales, visual interfaces and activities has been widely discussed as vital for cities (Alexander, 1965; Jacobs, 1992; Lynch, 1997). The interdependency between visual connections - or visual fields - and paths has been underlined as important for people's apprehension of the urban grid (Hillier et al., 1987). Correlations have been made between how well a global attribute can be perceived locally (relating global accessibility and a routes' direct connections); the higher the correlation, the more intelligible the area (Hillier, 1996), improving people's orientability (Medeiros, 2013). Correlations between topological radii helped characterize a wellworking diversity throughout the years in Clerkenwell, London (Perdikogianni \& Penn, 2005).

Considering community perception of urban areas, different traffic levels related to qualities of community life (Appleyard \& Lintell, 1969; Hart \& Parkhurst, 2011). Exceedingly high vehicular movement and wide avenues impacted on people having less local community bonds and feeling more vulnerable. High fluxes tended to sever the street, dividing both sides and weaken local urban life. This aspect was also considered as a spatial limit, according to Lynch's (1997) analysis of the image of the city. 


\section{The studied cases}

The neighbourhood hereby studied and named "Tambauzinho" encompasses the official neighbourhoods of Expedicionários, Tambauzinho and part of Miramar located south of Epitácio Pessoa Avenue (Figure 2). Tambauzinho is located geographically mid-way between the old city centre and the grids expansion - centralized by Epitácio Pessoa Avenue towards coastal areas in João Pessoa. Tambaú area is located further east, on the northern side of Epitácio Pessoa Avenue and has the sea as one of its limits. This area encompasses Tambau neighbourhood and a northern section of Miramar (Figure 1).

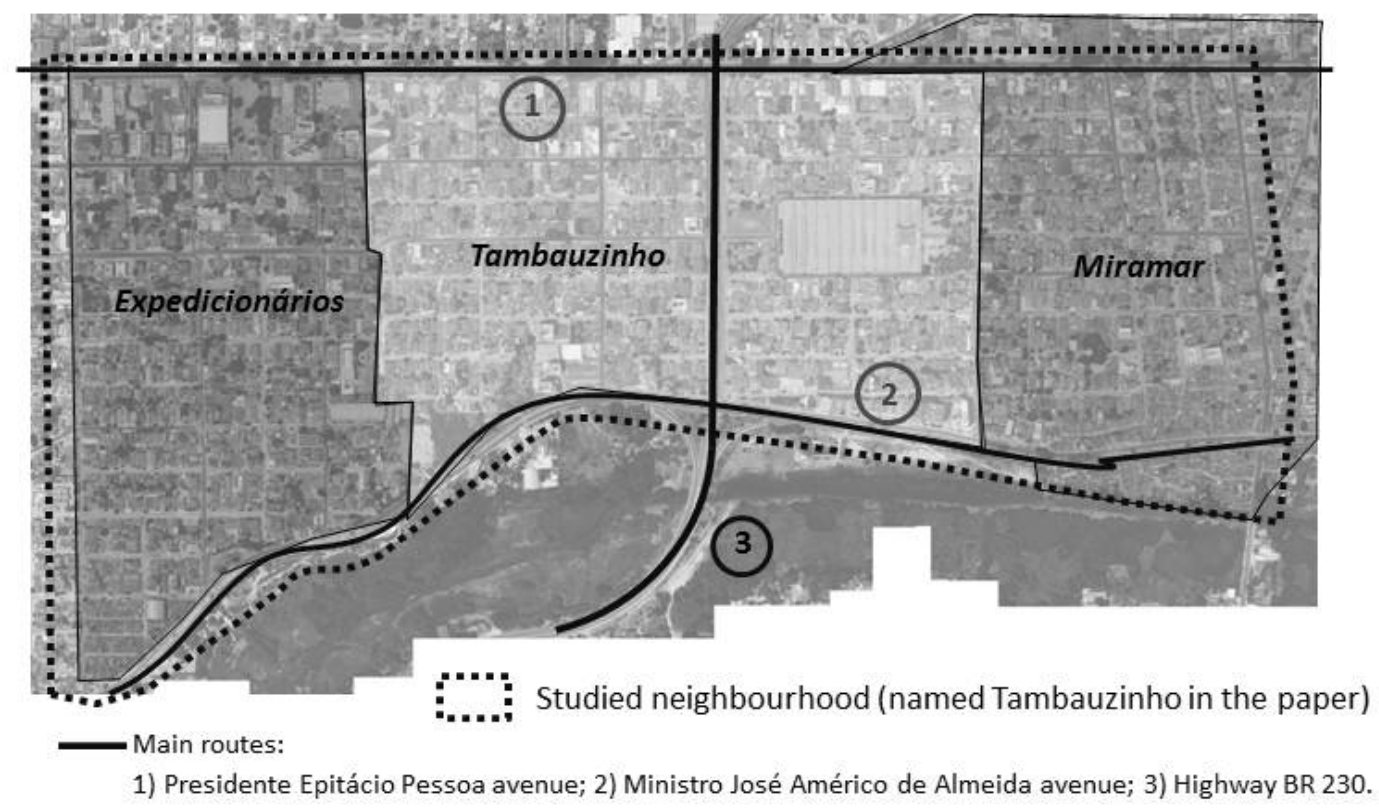

Figure 2 - Tambauzinho studied neighbourhood showing official municipal neighbourhoods and main routes. Source: Authors based on Google Earth Pro (2017).

Tambauzinho is limited on its north side by the wide and long linear Epitácio Pessoa Avenue (Figure 2). On its south the area is limited by the curved Ministro José Américo Almeida Avenue, commonly known as "Beira-Rio Avenue" as it borders the River Jaguaribe. Both routes have intense flux connecting through João Pessoa making east-western connections, from the city centre to the coastal. BR 230 highway passes transversally by the middle of Tambauzinho connecting northern neighbourhoods with the city's southern access, passing closely to the federal university (UFPB). The highway presents intense high-speed vehicular movement. The highway is situated at a lower level and four local streets of Tambauzinho pass over it, forming bridges without direct physical connections (Figure 3); spaces between the bridges are left as voids at Tambauzinho's street level. Tambaú is limited by Epitácio Pessoa Avenues on its south, Ruy Carneiro avenue on its north and the Atlantic ocean on its east, and does not have a major traffic route sectioning it. Internal block sizes and street sizes are more balanced and connections on street levels are more continuous (Figure 4). 

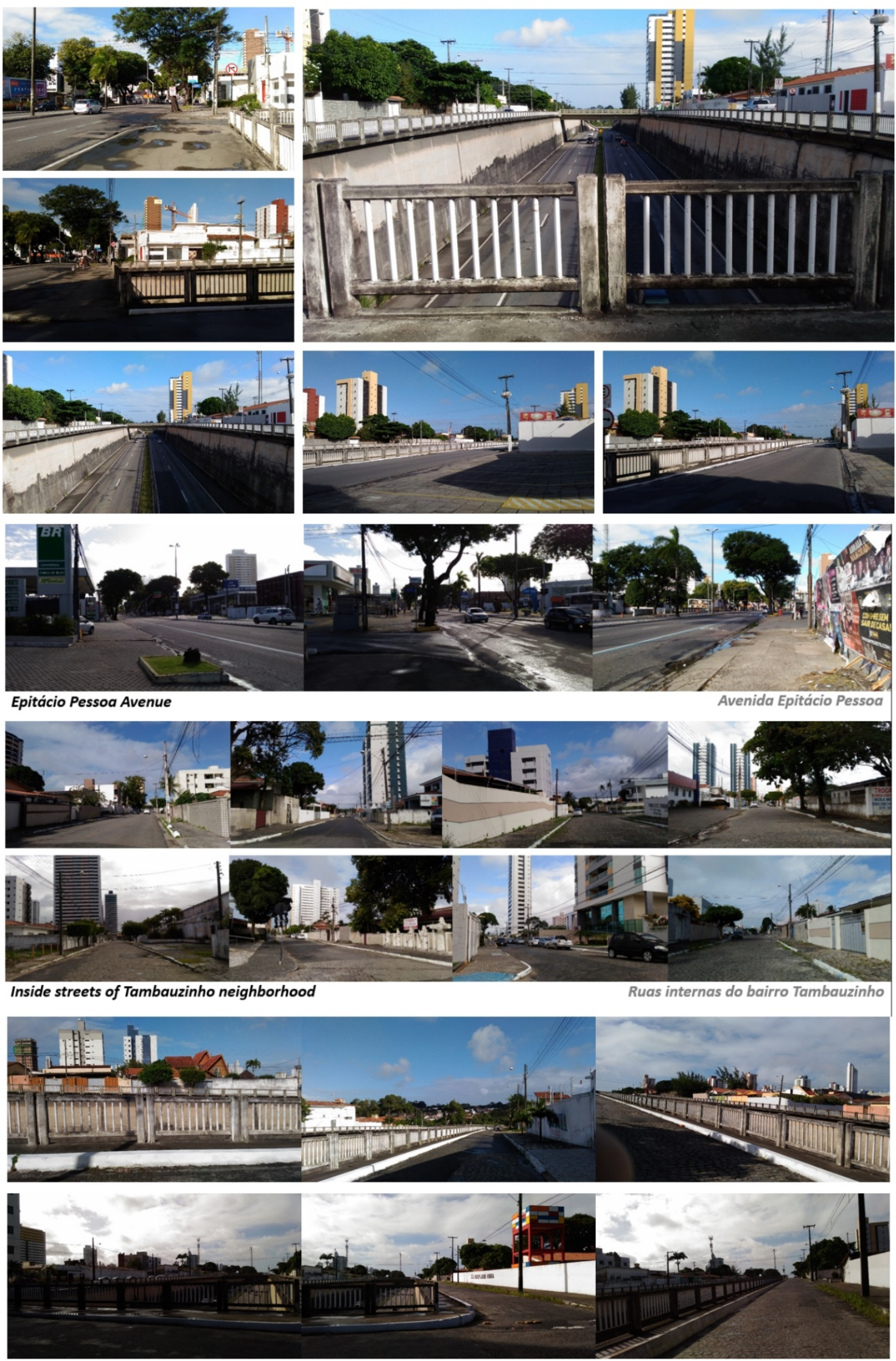

Federal highway BR 230 (below) and high neighborhood accesses

Rodovia federal BR 230 (abaixo) e acessos elevados do bairro

Figure 3 - Images of Avenida Epitácio Pessoa and Tambauzinho's internal streets. Source: Authors (2017). 


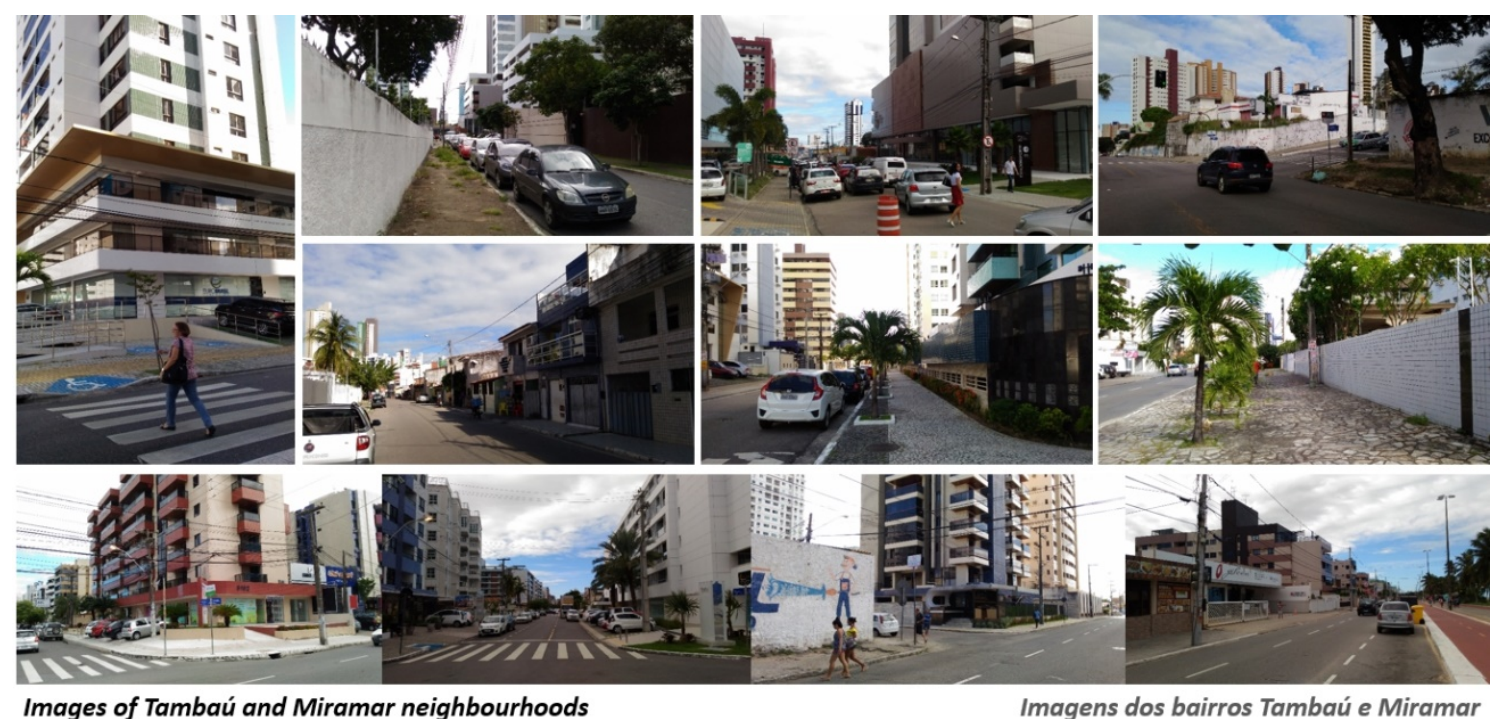

Figure 4 - Images of Tambaú neighbourhood at street level. Source: Authors (2018).

\section{Research method}

For the spatial configuration analysis, a linear representation of the city was built on georeferenced platform (QGIS), encompassing João Pessoa's official municipal boundaries (based on Castro \& Donegan's, 2017 map $^{2}$ ). This representation was processed at two modes of analysis in Depthmap (Varoudis, 2017). The axial map was processed for local (topological R3 radius) and global (Rn) scales. The angular segment analysis (ASA) map was processed at varied metric scales: 400, 800, 1200, 2400, 3200, 5000, 7000 and $\mathrm{n}$. ASA analysis considers differences within a line of movement, differentiating accessibility values for each block, and ponders angular deviations. Normalized values of integration (NAIN) approximating visitors potential movement, and normalized values of choice (NACH), approximating inhabitants potential movement, were processed (Hillier et al., 2012). Topological accessibilities are here expressed visually in maps by a colour scale, ranging from red for the most accessible spaces up to deep blue for the least accessible ones.

After processing at Depthmap, maps were visualized and analysed in QGIS, accessorized by the space syntax toolkit (Gil et al., 2015). To compare accessibility measures for the city and the neighbourhood at different scales (and correlations between), entities pertaining to Tambauzinho and to Tambaú areas were selected as separate layers for axial and ASA analysis.

Concerning built form analysis, survey visits were made to the area with pictures taken $(2016,2017)$, contemplating plots land use survey, producing thematic maps. Public transport to and within the area were also investigated. Spatial configuration and built form were then compared, and inter-related.

\section{Analysis}

\section{Spatial configuration}

João Pessoa city has a mainly fragmented urban grid, characterized by a rapidly evolving linear urban expansion, complemented by discontinuous urban grids. This characterizes many Brazilian cities, with urban grids resembling patchworks of neighbourhoods not well-knitted between themselves

\footnotetext{
${ }^{2}$ Linear representation of João Pessoa by Alexandre Castro and Lucy Donegan is available at Renato Saboya's website.
} 
(Medeiros, 2013). In João Pessoa various large natural boundaries (many of them river estuaries) have further contributed to this fragmentation and dispersal (Silveira et al., 2007), as few connections pass over these boundaries (Figure 5).

Distribution of global normalized integration (NAIN) levels in João Pessoa underline an accessible area surrounding the old city centre, spreading towards the coast through Tambauzinho (Figure 5), and towards the southwest of the old city centre through BR 230 highway and Cruz das Armas Avenue. While for axial analysis high integration values spread throughout the area, on ASA analysis accounting for angular deviations and differences for blocks - high levels concentrate more on Epitácio Pessoa Avenue.

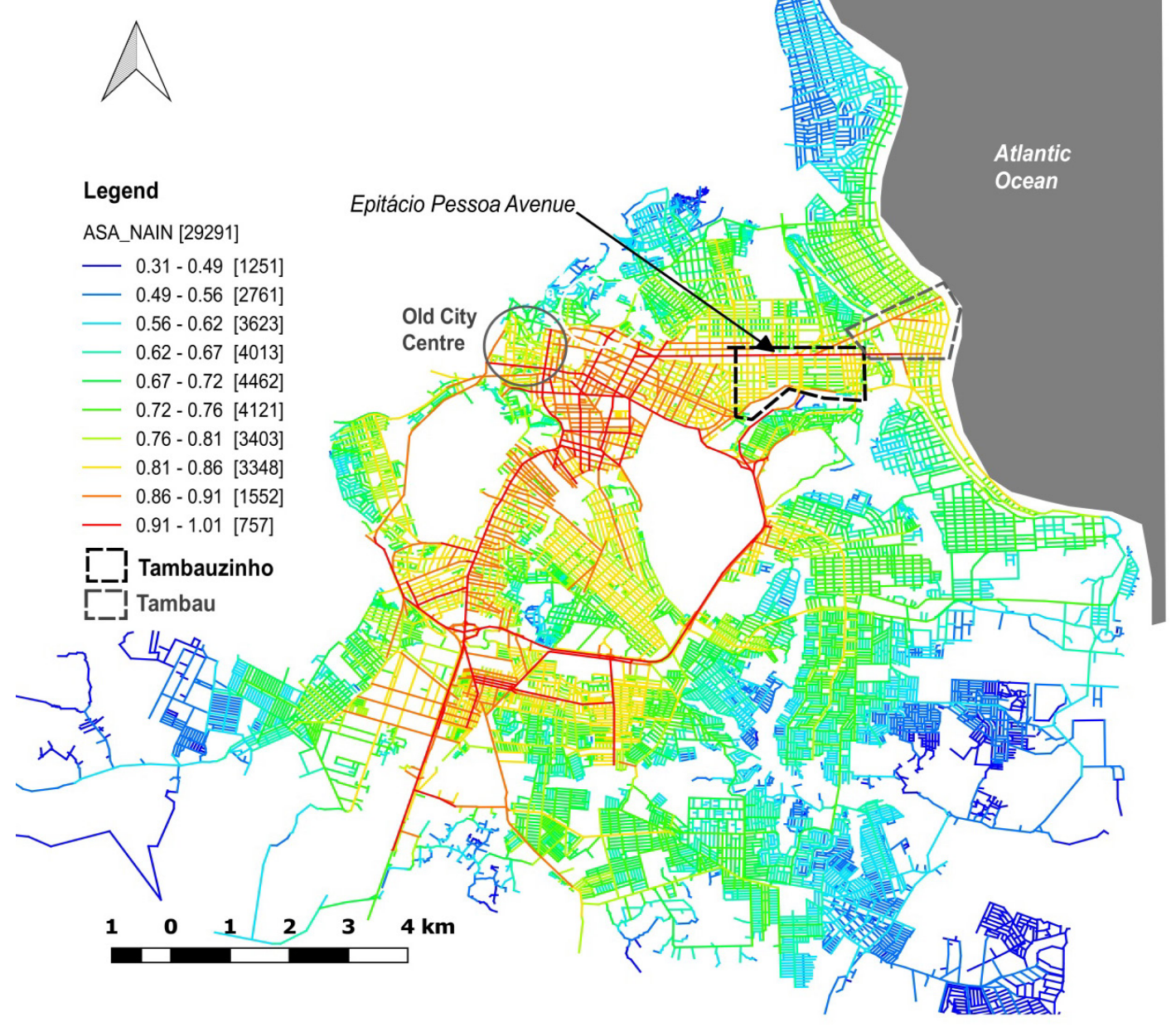

Figure 5 - João Pessoa's ASA map showing global normalized Integration. Source: Authors (2017).

The distribution of high global choice (NACH, Figure 6) underlines a less concentrated system of routes spreading further away from the old city centre; these reinforce main expansion routes towards different areas of the system, especially the highway BR 230, located east of the botanical preservation area, and crossing the city in a mainly north-south direction, with many curves. 


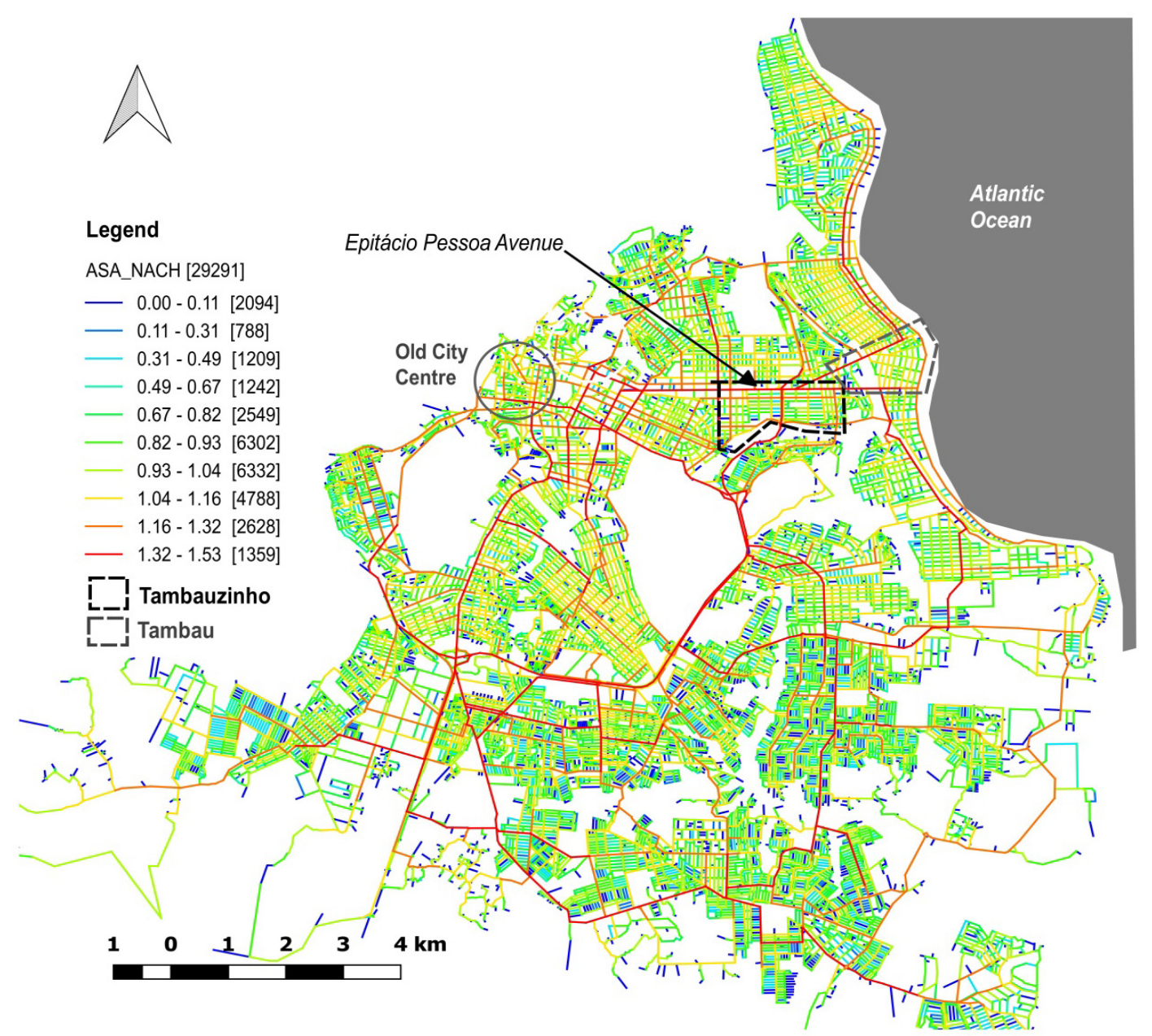

Figure 6 - João Pessoa's ASA map showing global normalized choice. Source: Authors (2017).

Axial accessibility levels for the neighbourhood and the city (Table 1) highlight Tambauzinho and Tambaú as areas with privileged accessibility, reaching high average levels at all studied radii.

Table 1 - Axial map accessibility levels, minimum, maximum and average

\begin{tabular}{|c|c|c|c|c|c|c|c|c|c|}
\hline \multirow{2}{*}{$\begin{array}{c}\text { SYSTEM } \\
\text { (number of axes) }\end{array}$} & \multicolumn{3}{|c|}{ MIN } & \multicolumn{3}{|c|}{ MAX } & \multicolumn{3}{|c|}{ AVERAGE } \\
\hline & Con & R3 & $\mathbf{R n}$ & Con & R3 & Rn & Con & R3 & $\mathbf{R n}$ \\
\hline JOÃO PESSOA (10858) & 1 & 0.333 & 0.196 & 58 & 4.664 & 0.610 & 3.565 & 1.796 & 0.448 \\
\hline TAMBAUZINHO (124) & 1 & 0.333 & 0.386 & 58 & 4.509 & 0.574 & 5.621 & 2.344 & 0.513 \\
\hline TAMBAU (83) & 1 & 0.985 & 0.475 & 58 & 4.512 & 0.572 & 5.265 & 2.574 & 0.519 \\
\hline
\end{tabular}

Source: Authors (2018).

Table 2 - Correlations between accessibilities at topological scales: Global (Rn), Local (R3) and on the street (connectivity)

\begin{tabular}{cccc}
\hline SYSTEM & \multicolumn{3}{c}{ CORRELATIONS ( $\left.\mathbf{r}^{2}\right)$} \\
\cline { 2 - 4 } (number of axes) & Rn-con & Rn-R3 & R3-Con \\
\hline JOÃO PESSOA (10858) & 0.041 & 0.181 & 0.440 \\
TAMBAUZINHO (124) & 0.167 & 0.768 & 0.358 \\
TAMBAU (83) & 0.151 & 0.786 & 0.274 \\
\hline
\end{tabular}

Source: Authors (2018). 
Although correlations between global and local topological correlations are significant for Tambauzinho amd Tambaú (over 0.40), correlations between integration (Rn and R3) and connectivity (labelled con, Table 2) are low, especially between global integration and connectivity (Rn-con: 0.167 for Tambauzinho, 0.151 for Tambaú). This points to both areas' little intelligibility: global scale hierarchies of streets can barely be seen by users at a street level, which might be thus hindering people's orientability within the sectors. The mostly orthogonal grid within the area is set in a way that differences in larger scale potential movement cannot be perceived and interpreted for navigability within the sector. This somewhat homogeneous landscape locally might be one of the spatial attributes relating to some day-today descriptions of Tambauzinho as a "meaningless" area, or of lacking a well-defined identity.

The neighbourhoods system presents high overall average accessibility levels for potential to (NAIN values, Table 3) and through-movement (NACH values, Table 4) for almost all ASA metric scales. This reinforces the axial analysis and Tambauzinho and Tambaú's privileged positions in the city's grid. Tambauzinho's grid only reaches low average levels for local NACH values, indicating low differences in hierarchy for shorter trips for local pedestrians. However, when we look at the distribution of high global NACH values (Figure 5), at Tambauzinho these are set at the areas' borders or at the highway passing under it. For Tambau average levels of NACH and NAIN are slightly higher, and are not so concentrated at its borders, as medium accessibilities (yellow colouring) pass through the area, expressing a somewhat smoother distribution of potential movement for habitants and inhabitants through the area.

Table 3 - Normalized integration (NAIN) values for Angular Segment Analysis (ASA)

\begin{tabular}{|c|c|c|c|c|c|c|c|c|c|c|c|c|c|c|}
\hline \multicolumn{15}{|c|}{ NAIN (Normalized Integration) } \\
\hline \multirow{2}{*}{$\begin{array}{c}\text { SYSTEM } \\
\text { (number of } \\
\text { segments) }\end{array}$} & \multicolumn{5}{|c|}{ MIN } & \multicolumn{5}{|c|}{ MAX } & \multicolumn{4}{|c|}{ AVERAGE } \\
\hline & 400 & 1200 & 2400 & 5000 & $\mathbf{n}$ & 400 & 1200 & 2400 & 5000 & $\mathbf{n}$ & 400 & 1200 & 2400 & 5000 \\
\hline $\begin{array}{c}\text { JOÃO PESSOA } \\
(29291)\end{array}$ & 0.363 & 0.343 & 0.286 & 0.259 & 0.311 & 3.148 & 2.528 & 2.090 & 1.683 & 1.013 & 1.300 & 1.111 & 0.989 & 0.8780 .697 \\
\hline $\begin{array}{c}\text { TAMBAUZINHO } \\
(407)\end{array}$ & 0.521 & 0.425 & 0.464 & 0.593 & 0.311 & 2.226 & 2.156 & 1.855 & 1.673 & 0.923 & 1.420 & 1.284 & 1.109 & 1.2210 .810 \\
\hline TAMBAU (337) & 0.759 & 0.812 & 0.889 & 0.866 & 0.685 & 2.281 & 2.115 & 1.915 & 1.636 & 0.824 & 1.521 & 1.498 & 1.409 & 1.2860 .824 \\
\hline
\end{tabular}

Source: Authors (2018).

Table 4 - Normalized Choice (NACH) values for Angular Segment Analysis (ASA)

\begin{tabular}{|c|c|c|c|c|c|c|c|c|c|c|c|c|c|c|c|}
\hline \multicolumn{16}{|c|}{ NACH (Normalized Choice) } \\
\hline \multirow{2}{*}{$\begin{array}{c}\text { SYSTEM } \\
\text { (number of } \\
\text { segments) }\end{array}$} & \multicolumn{5}{|c|}{ MIN } & \multicolumn{5}{|c|}{ MAX } & \multicolumn{5}{|c|}{ AVERAGE } \\
\hline & 400 & 1200 & 2400 & 5000 & $\mathbf{n}$ & 400 & 1200 & 2400 & 5000 & $\mathbf{n}$ & 400 & 1200 & 2400 & 5000 & $\mathbf{n}$ \\
\hline $\begin{array}{c}\text { JOÃO PESSOA } \\
(29341)\end{array}$ & 0 & 0 & 0 & 0 & 0 & 1.832 & 1.712 & 1.679 & 1.509 & 1.533 & 0.985 & 1.002 & 0.975 & 0.941 & 0.868 \\
\hline $\begin{array}{c}\text { TAMBAUZINHO } \\
(407)\end{array}$ & 0 & 0 & 0 & 0 & 0 & 1.461 & 1.466 & 1.419 & 1.472 & 1.492 & 0.965 & 1.041 & 1.023 & 1.029 & 0.962 \\
\hline TAMBAU (337) & 0 & 0 & 0 & 0 & 0 & 1.408 & 1.479 & 1.479 & 1.476 & 1.497 & 1.040 & 1.115 & 1.110 & 1.091 & 1.017 \\
\hline
\end{tabular}

Source: Authors (2018).

Although the neighbourhoods are generally privileged in accessibility at many radii, both areasexcel at some intermediate scales, as at R5000 metres, especially for NAIN values (Figure 7). This scale approximates city dynamics (Serra \& Pinho, 2013), an intermediate scale between the neighbourhood (from 400 to $1200 \mathrm{~m}$ ), and the region (over $7000 \mathrm{~m}$ ). R5000 metric scale analysis underlines areas of João Pessoa more continuous to each other and form an expansion core from the old city centre towards the coast; this connects to a mainly continuous grid following the coast (especially by Tambaú neighbourhood) and spreading north. It indeed seems to reflect areas in the city intensely used for day-to-day movement, concentrating most significant high-rise buildings and diverse and economically activities in the city. On the other hand, global accessibility levels highlight routes that (Figure 5 and 6), although important in 
articulating the system as a whole, do not present built form continuity in concentrating densely and diversely used activities.

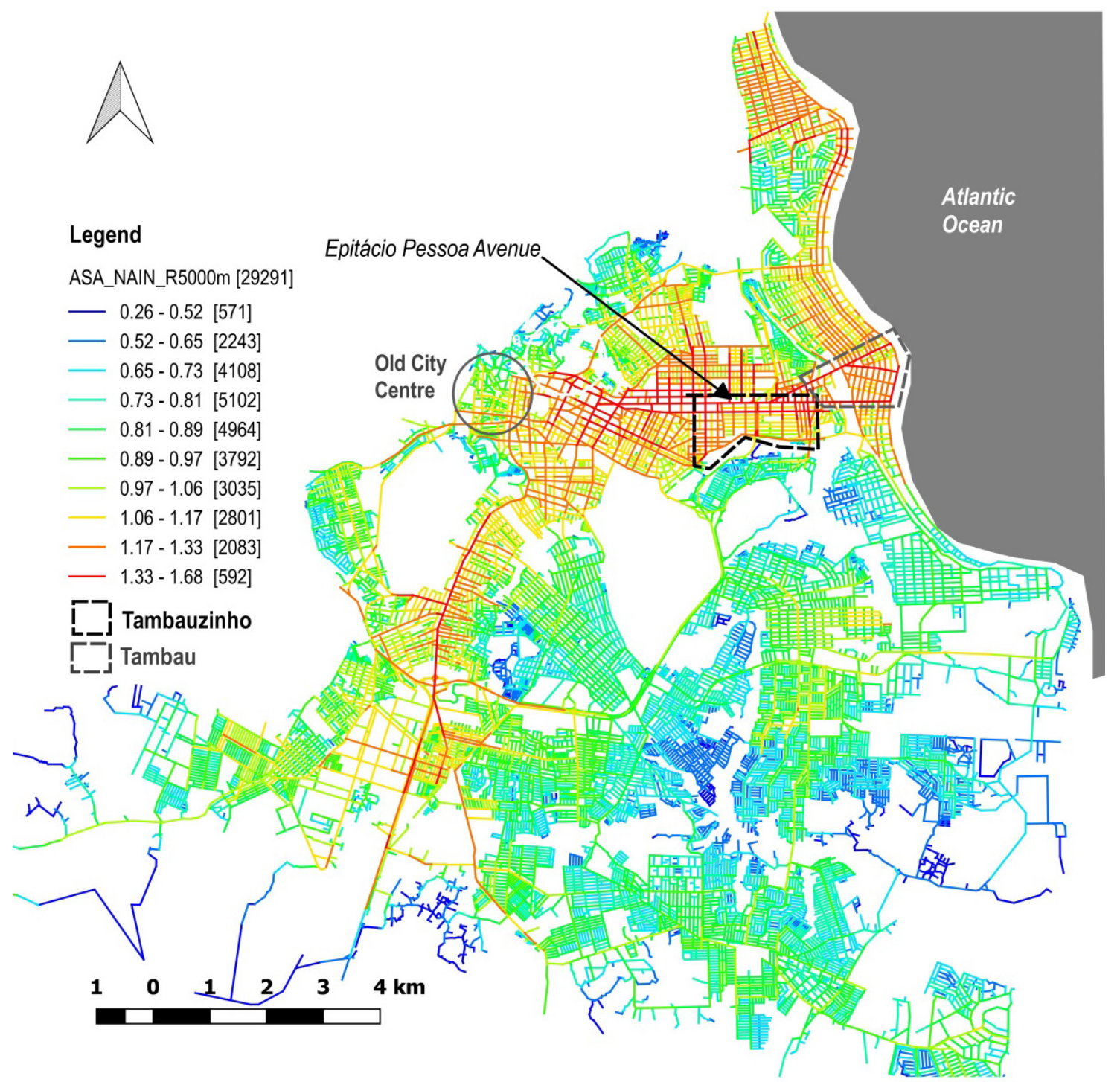

Figure 7 - João Pessoa's ASA map showing normalized integration at radius $5000 \mathrm{~m}$. Source: Authors (2017).

\section{Land uses and street level connections}

Observing the distribution of non-residential uses within Tambauzinho (Fraction 1), there is a concentration of commercial uses at Epitácio Pessoa avenue (Figure 8). Such concentration of activities follows its high hierarchy for potential movement at various modes and radii of analysis. Furthermore, this avenue also has the highest connectivity in the city (axial analysis), being thus also perceived at street level as an important route for movement in the city. For Tambaú (Fraction 2) non-residential uses spread more throughout the area.

Commercial activities within the sector either concentrate or approximate Epitácio Pessoa avenue. Other commerce in the sector pulverize within the neighbourhood so that there aren't any other continuous commercial strips. 


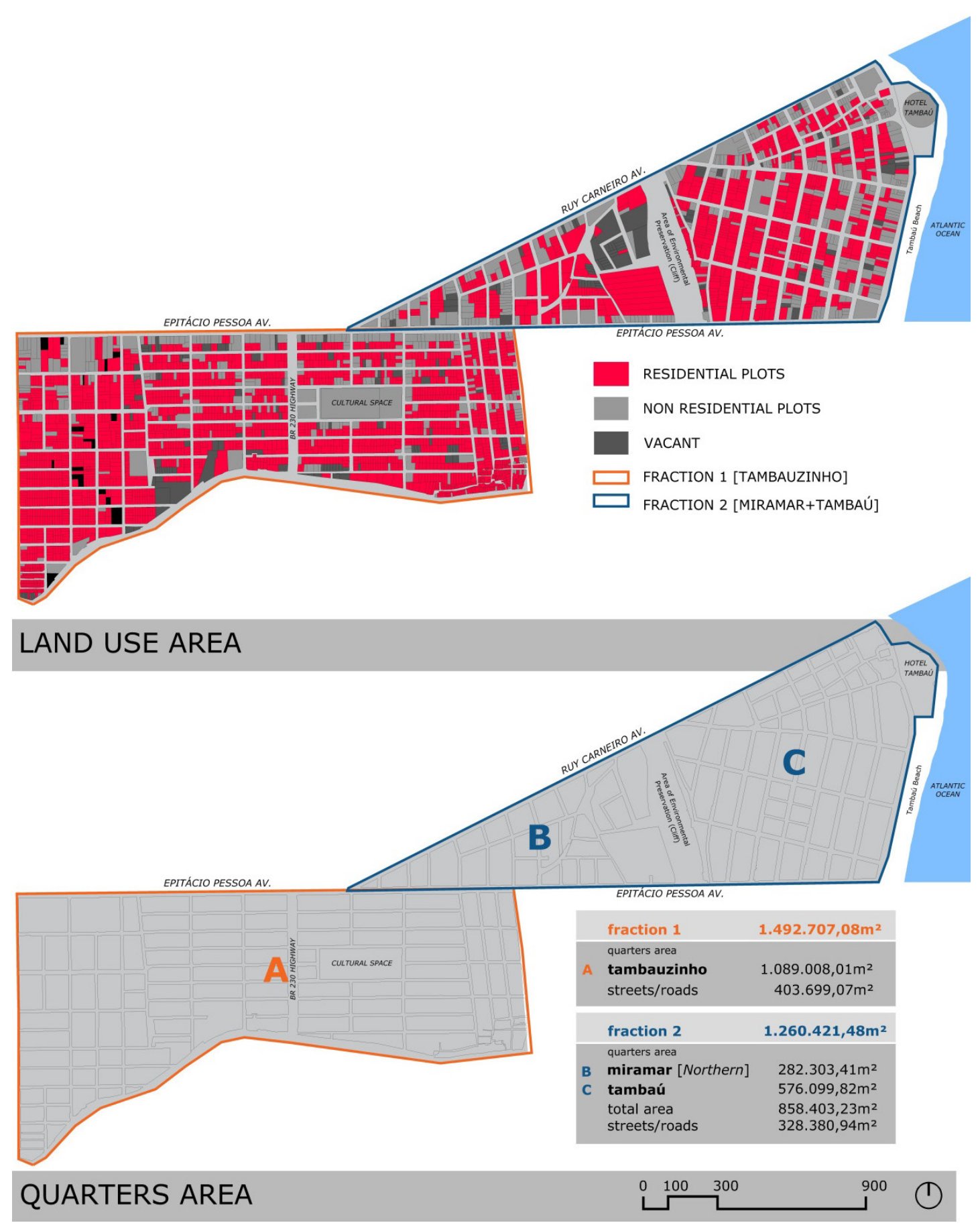

Figure 8 - Areas and land uses for Tambauzinho and Tambaú indicating main avenues and Cultural Space. Source: Authors (2018).

Although there are some institutional uses in Tambauzinho, they do not seem to promote a lively and diverse neighbourhood; surroundings do not show a concentration of complementary activities, as commerce. Most lively areas are mainly a buffer of activities happening at Epitácio Pessoa Avenue. The largest institutional use within the area, the cultural space (Espaço Cultural José Lins do Rego) occupies a large block cutting two local thoroughfares and thus also seems to somehow hinder local movement in the area (Figure 8). Although this cultural space attracts users for its daily events, more intense uses happen in a sporadic frequency and does not seem to knit well to neighbouring areas: land uses around it do not seem to benefit from it as only some smaller commerce, and mostly residences are set around it. This matches our local observations of people reaching and leaving specific places mostly by car. 
Comparing numbers with Tambaú, overall residential areas and percentage of plots with residential uses are higher in Tambauzinho (Table 5).

Table 5 - Quantification of residential, non-residential and vacant areas (in $\mathrm{m}^{2}$ ), and percentages for the neighborhoods of Fractions 1 and 2

\begin{tabular}{cccccccc}
\hline NEIGHBOURHOODS & \multirow{2}{*}{ RESIDEN. } & \multirow{2}{*}{ NON RESIDEN } & $\begin{array}{c}\text { UNUSED } \\
\text { AREAS }\end{array}$ & TOTAL PLOTS & $\begin{array}{c}\text { STREETS/ } \\
\text { ROADS }\end{array}$ & $\begin{array}{c}\text { RESIDENTIAL } \\
\%\end{array}$ & $\begin{array}{c}\text { VACANT } \\
\%\end{array}$ \\
\hline TAMBAUZINHO & $760.219,00$ & $247.233,77$ & $81.555,24$ & $1.089 .008,01$ & $403.699,07$ & $\mathbf{7 0}$ & $\mathbf{7}$ \\
TAMBAÚ & $495.387,38$ & $289.104,83$ & $73.911,02$ & $858.403,23$ & $328.380,94$ & $\mathbf{5 8}$ & $\mathbf{9}$ \\
Total & $\mathbf{1 . 2 5 5 . 6 0 6 , 3 8}$ & $\mathbf{5 3 6 . 3 3 8 , 6 0}$ & $\mathbf{1 5 5 . 4 6 6 , 2 6}$ & $\mathbf{1 . 9 4 7 . 4 1 1 , 2 4}$ & $\mathbf{7 3 2 . 0 8 0 , 0 1}$ & $\mathbf{6 4}$ & $\mathbf{8}$ \\
\hline
\end{tabular}

Source: Authors (2018).

Little distribution of commerce within Tambauzinho matches our observations of few people walking on the streets (exemplified in Figures 3, 4 and 8, and Table 5); people mostly tend to reach specific places by car rather than walking. Such situation is also induced by small distribution of mobility infrastructure in the area. Public transport systems also concentrate on Epitácio Pessoa avenue and there are no cycling routes, accentuating automotive dependency. People arriving by bus have to walk up to 700 meters to reach the other far-end of this area; pedestrian accesibility is worsened by the poor quality of sidewalks, as not being large enough, presenting abrupt changes in level and few trees to offer shade and a more agreeable climate for walking (Figures 3, 4 and 9). Again, most trees in public spaces are set at the wider Epitácio Pessoa and Ministro José Américo de Almeida avenues.

Besides Av. Epitácio Pessoa, another highly acessible route located within Tambauzinho is BR 230 Highway (Figures 8, 9 and 10). However, this route is situated at a lower level and is detached from the neighbourhood surroundings. It resembles an artificial canyon over which four routs bridge over it allowing for two lanes for cars with narrow sidewalks. Up to last year, there were only three connections, two of them the larger avenues marking the limits of Tambauzinho area (Epitácio Pessoa and Ministro José Américo de Almeida, Figure 2), the third connection is a route set midway in Tambauzinho, Rua Arquiteto Hermenegildo Di Lascio, which is interrupted by the Cultural Space shortly after bridging the highway. Last year a fourth connection was built midway Epitácio Pessoa Avenue and Rua Arquiteto Hermenegildo Di Lascio (connecting the streets José Florentino Júnior and Deputado Geraldo Mariz), and represents an alternative east-west route to Epitácio Pessoa Avenue, although it does not reach as far as the coastal neighbourhood.

The highway situation helps to split the area in half and hinders urban vitality in a few ways: (i) potential movement of this route is lost as there are no potential interfaces at street level; (ii) its wideness and created voids separate both sides of Jader Medeiros street at the neighbourhood level (Figure 9); (iii) few local streets pass over it making probable local routes longer in east-western directions; (iv) the poor quality for pedestrians, as the crossing of these streets contemplate only the vehicular route and a narrow pedestrian sidewalk, with no natural shades along this. It is very difficult to maintain effective natural surveillance on Jader Medeiros street making it a hostile environment for pedestrians, distances are made longer with no effective activities. This is also expressed, and reinforced, by there being very few non-residential uses at this street, and mainly blank walls (Figure 9).

At Tambaú as a whole buildings are higher, presenting more commerces and services at ground level, and still some residences (Figure 8 and 9). This follows its spatial configuration, of an urban grid slighltly more accessible at average and, mainly, with accessibilities more distributed through the neighbourhood. This scenario also agrees with a less fragmented urban design at street level, where boundaries are mostly natural ones (especially for nothern miramar, Figure 9), however movement internally seems more easy and is accompanied by stronger interfaces (Figure 4). 


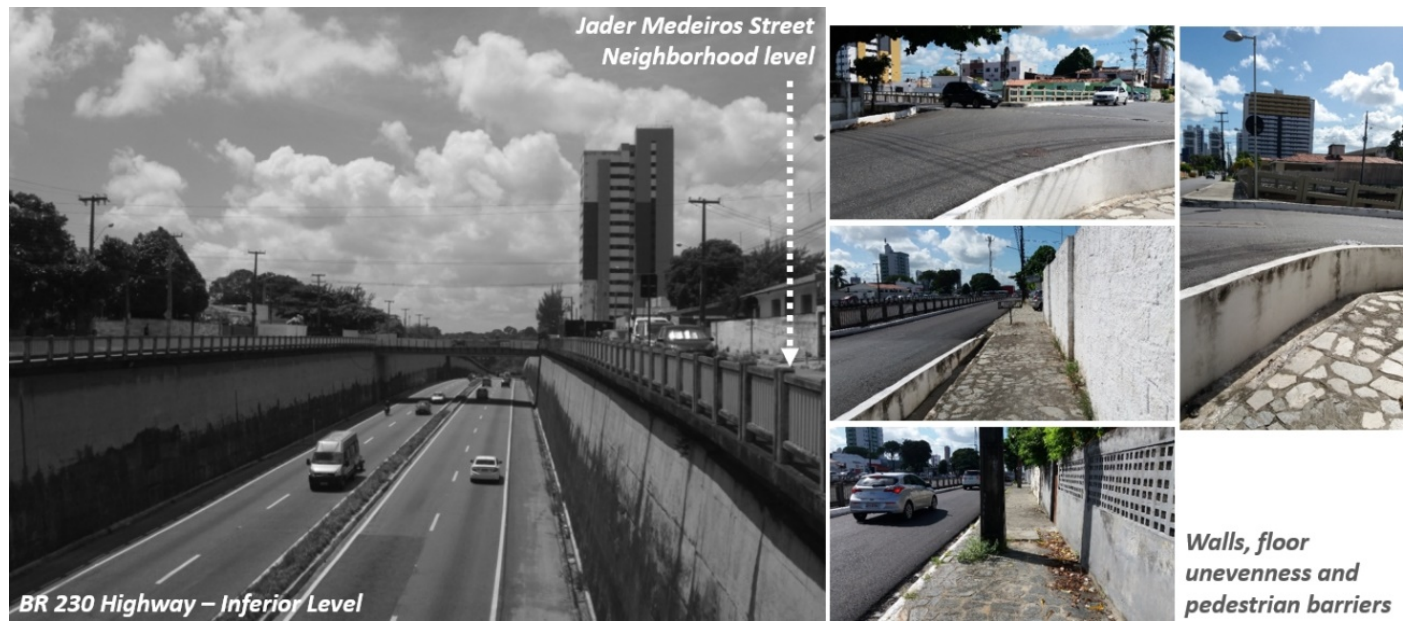

Figure 9 - Images of the federal highway BR 230 (left) and surrounding sidewalks at Tambauzinho street level (right). Source: Authors (2017).

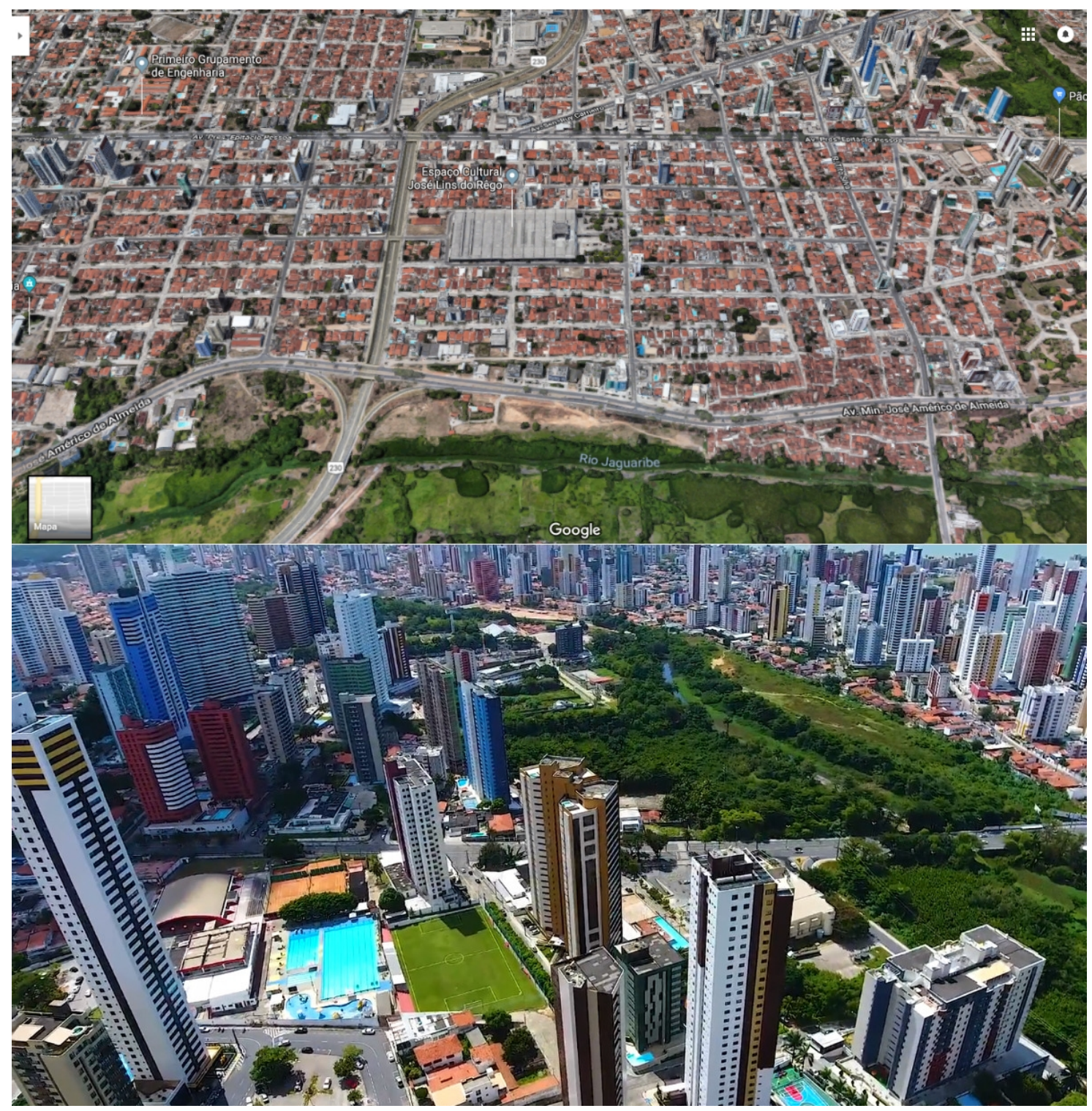

Figure 10 - Aerial view of the Tambauzinho neighbourhood (Fraction 1) and Miramar e Tambaú neighbourhoods (Fraction 2). Source: Adapted from Google Maps (2018) and Execut Negócios Imobiliários (2018). 


\section{Discussion}

Although this thorough-fare is prominently accessible globally within João Pessoa's system and especially at a city scale, Tambauzinho actual uses and built form do not seem to resonate such a privileged position, in that it does not represent such a lively and diverse area. On the other hand Tambaú, although not so central geometrically within the city as Tambauzinho, reaches higher topological accessibility levels and a livelier nighbourhood. This paper argues that the potential movement configured by the urban grid and the central location of Tambauzinho is further hindered by other local spatial attributes, as the discontinuity in visual fields and the lack of continuity in movement and the poor quality of sidewalks for pedestrians through the neighbourhood. Low intelligibility levels in this area may account for what is commonly described of the area as being a "meaningless" area.

Most of the diverse activities at Tambauzinho do not enter the area, concentrating on Epitácio Pessoa Avenue or up to two blocks away from it. Epitácio Pessoa is the most connected avenue in the city, reaching from the city centre expansion towards João Pessoa coastal areas. This follows Brazilian cities fast and linear growing tendency and corroborating Villaça's (2001) studies. Such linear-oriented growing dynamic - with urban grids mainly being filled-in disruptively at different times by different managements - contributes to a scenario well-known for Brazilian cities', as extremely fragmented cities where background grids are not well connected with each other resembling patchworks (Medeiros, 2013).

Tambauzinho spatial problems are underlined by a lack of a continuous urban space and the rupture in community life caused by highways cutting the city, as pointed out in other studies (Appleyard \& Lintell, 1969; Hart \& Parkhurst, 2011), and a symptom of a vehicular traffic oriented planning. Other infrastructure problems of many Brazilian cities - as a poor distribution of public transport and community facilities - are present in the studied neighbourhood, revealing an overall incomprehensive urban planning that does not contemplate other modes of transportation (besides vehicular).Some possible interventions for public urban management cuold address and/or subdue spatial fragmentation in Tambauzinho. One of these would be to offer infrastructure for pedestrians and cyclists, aided by landscape and signalling designs to create quality spaces to walk on, especially in between the avenues located at the extremes north and south of the area (respectively Epitácio Pessoa and José Américo Almeida Avenues). Another, perhaps more complex, intervention would be to open more active interfaces (instead of walls), and promote more dense built and demographic occupation (over the existing 80 dwellers/hectare and closer to 250 dwellers/hectare, as advised by Jacobs, 1992). A third possible strategy would be to encourage low-rise building types accommodating more dwellers (instead of the newly built high-rise blocks), aiming to optimise public/private interfaces and streets use by people, facilitating urban liveliness. Such interventions might include built incentives to be worked together with urban planning policies.

Although the movement and built form fragmentation problem brought by the highway situation in Tambauzinho would demand large-scale structural interventions to be reverted, there are some possible smaller scale interventions that can help ease divisions, as to fully bridge the gap between both sides of Jair Medeiros Avenue, transforming what resembles now a canyon into a tunnel. On the neighbourhood level this would allow public appropriation of spaces set in the middle of the area and, if maintained properly, provide a large public space for the city and help connect a divided neighbourhood, giving more space for pedestrians. Although Tambaú has more natural boundaries, it still reaches a livelier built form and allows for more to and through movement, helped by local ways in which routes and buildings were established. Such comparisons between neighbourhood studies can also help rehearse possible scenarios for future interventions even encompassing changes of the streets topological connections.

There are many possible avenues of further research, the next steps contemplate mapping actual uses by people (in intensity and spatial distribution within the neighbourhood) and of types of interfaces between public and private areas. Studies in a finer grain of the built form (e.g. footprint, 
building height and different types of density levels) might help develop better notions of interventions and clarify possible positive outcomes within the community.

\section{Acknowledgements}

To the Brazilian funding agencies CAPES for the main author's post-doctoral scholarship.

\section{References}

Alexander, C. (1965). A city is not a tree. The Architectural Forum, 122(1-2), 58-62.

Appleyard, D., \& Lintell, M. (1969). The environmental quality of the city streets: the residents' view point. Environmental Design Research Association, 2, 11-2-0-11-2-10.

Berghauser Pont, M., \& Haupt, P. (2005). The spacemate: density and the typomorphology of the urban fabric. Nordisk Arkitekturforskning, 18(4), 55-68.

Castro, A. A. B. C., Melo, R. A., \& Silveira, J. A. R. (2016). Interfaces rodoviário-urbanas na produção da cidade: estudo de caso do contorno rodoviário de João Pessoa - PB. João Pessoa: Paraiboa.

Castro, A., \& Donegan, D. (2017). Retrieved in 2017, December 20, from http://urbanidades.arq.br/mapasconfiguracionais

Donegan, L., \& Trigueiro, E. B. F. (2016). To each, their beach: unveiling nexus between architecture and society in urban beaches. The Journal of Space Syntax, 7(1), 87-106.

Execut Negócios Imobiliários. (2018) Imagem do bairro Miramar, Tambaú e Manaíra. João Pessoa. Retrieved in 2018, June 25, from https://execut.com.br/blog/bairros/conheca-o-bairro-de-miramar-em-joao-pessoa

Ferraz, V. S. (2008). Turismo cultural na ZEPH-Ribeira: possibilidades e Limitações. Natal: UFRN.

Gil, J., Varoudis, T., Karimi, K., \& Penn, A. (2015). The space syntax toolkit: integrating depthmapX and exploratory spatial analysis workflows in QGIS. In Proceedings of the 10th International Space Syntax Symposium (pp. 148:1148:12). London: Space Syntax Laboratory, The Bartlett School of Architecture, University College London.

Google Earth Pro. (2017). Imagem de Tambauzinho em João Pessoa. Retrieved in 2017, July 20, from https://www.google.com.br

Google Maps. (2017). Imagem de João Pessoa de 2018. Retrieved in 2017, December 18, from https://www.google.com.br/maps/@-7.1171888,-34.8515022,12.96z

Google Maps. (2018). Imagem 3D do bairro Tambaú, Miramar, Expedicionários e Tambauzinho de 2018. Retrieved in 2018, June 20, from https://www.google.com.br/maps/@-7.1280955,-

$34.8423977,1601 \mathrm{a}, 35 \mathrm{y}, 39.02 \mathrm{t} /$ data $=$ !3m1!1e $3 ! 5 \mathrm{~m} 1$ ! $1 \mathrm{e} 4$

Hart, J., \& Parkhurst, G. (2011). Driven to excess: impacts of motor vehicles on the quality of life of residents of three streets in Bristol UK. World Transport Policy and Practice, 17(2), 12-30.

Hillier, B. (1996). Space is the machine: a configurational theory of architecture. London: Space Syntax. Retrieved in 2018, June 20, from http://eprints.ucl.ac.uk/3881/

Hillier, B. (2009). Spatial sustainability in cities: organic patterns and sustainable forms (pp. K01:1-K01:20). In Proceedings of the 7th International Space Syntax Symposium. Stockholm: KTH.

Hillier, B., \& Hanson, J. (1984). The social logic of space. Cambridge: Cambridge University Press. http://dx.doi.org/10.1017/CB09780511597237.

Hillier, B., \& Vaughan, L. (2007). The city as one thing. Progress in Planning, 67, 205-230.

Hillier, B., Burdett, R., Peponis, J., \& Penn, A. (1987). Creating life: or, does architecture determine anything? Architecture and Behaviour, 3(3), 233-250. 
Hillier, B., Penn, A., Hanson, J., Grajewski, T., \& Xu, J. (1993). Natural movement: or, configuration and attraction in urban pedestrian movement. Environment and Planning. B, Planning \& Design, 20(1), 29-66.

http://dx.doi.org/10.1068/b200029.

Hillier, B., Yang, T., \& Turner, A. (2012). Normalising least angle choice in Depthmap-and how it opens up new perspectives on the global and local analysis of city space. Journal of Space Syntax, 3(2), 155-193.

Jacobs, J. (1992). The death and life of great American cities. New York: Vintage Books.

Lynch, K. (1997). A imagem da cidade. São Paulo: Martins Fontes.

Medeiros, V. (2013). Urbis Brasiliae: o labirinto das cidades brasileiras. Brasília: Editora Universidade de Brasília.

Medeiros, V., Trigueiro, E., \& Gonçalves, A. P. B. (2009). Mapas que revelam um olhar: a expansão urbana de Natal sob a ótica de fatores estratégicos. In Anais do III Simpósio Luso-Brasileiro de Cartografia Histórica. Ouro Preto: UFMG.

Nascimento, R. C. (2011). Natal! Qual é a sua cara? Análise do processo de formação e transformação edilícia da avenida Eng. Roberto Freire (Natal/RN). Natal: UFRN.

Peponis, J. (1989). Space, culture and urban design in late urbanism and after. Ekistics, 56(334-335), 93-108.

Perdikogianni, I., \& Penn, A. (2005). Measuring diversity: a multi-variate analysis of land use and temporal patterning in Clerkenwell. In Proceedings of the 5th International Space Syntax Symposium (Vol. 2, pp. 741-761). Delft: Techne Press.

Salingaros, N. A. (1998). Theory of the urban web. Journal of Urban Design, 3(1), 53-71. http://dx.doi.org/10.1080/13574809808724416.

Serra, M. L. A., \& Pinho, P. (2013). Tackling the structure of very large spatial systems: space syntax and the analysis of metropolitan form. The Journal of Space Syntax, 4(2), 179-196.

Silveira, J. A. R., Lapa, T. A., \& Ribeiro, E. L. (2007). Percursos e processo de evolução urbana: uma análise dos deslocamentos e da segregação na cidade. Arquitextos, 8, 090.04.

Van Nes, A., \& López, M. J. (2007). Micro scale spatial relationships in urban studies: the relationship between private and public space and its impact on street life. In Proceedings of the 6th International Space Syntax Symposium (pp. 023). Istanbul: ITU.

Varoudis, T. (2017). depthmapX Multi-Platform Spatial Network Analysis Software (Version 0.35). London: Space Syntax Laboratory, UCL. Retrieved in 2018, June 20, from http://archtech.gr/varoudis/depthmapX/

Vaughan, L. S., Dhanani, A., \& Griffiths, S. (2013). Beyond the suburban high street cliché: a study of adaptation to change in London's street network: 1880-2013. Journal of Space Syntax, 4(2), 221-241.

Vaughan, L., Khan, S. S., Tarkhanyan, L., \& Dhanani, A. (2017). The spatial configuration of minority ethnic business diversity in London's high streets. In Proceedings of the 11th International Space Syntax Symposium (pp. 15.115.12). Lisboa: Instituto Superior Técnico.

Vaughan, L., Törmä, I., Dhanani, A., \& Griffiths, S. (2015). An ecology of the suburban hedgerow, or: How high streets foster diversity over time. In Proceedings of the 10th International Space Syntax Symposium (pp. 99:199.19). London.

Villaça, F. (2001). Espaço intra-urbano no Brasil. São Paulo: Studio Nobel: FAPESP.

Yang, T., \& Hillier, B. (2012). The impact of spatial parameters on spatial structuring (pp. 8019:1-8019:23). In Proceedings of the Eighth International Space Syntax Symposium. Santiago de Chile: PUC.

Editor: Rodrigo Firmino

Received: Jan. 31, 2018

Approved: Oct. 13, 2018 